12. Andrews K. Elizabethan Privateering: English Privateering during the Spanish War. Cambridge, 1964. $314 \mathrm{p}$.

13. Губарев В.К. Флибустьерский кодекс: образ жизни и обычаи пиратов Карибского моря (60-90-е гг. XVII в.) // Наука. Религия. 2005. № 3. С. 39-49.

14. Burgess D. Piracy in the Public Sphere: The Henry Every Trials and the Battle for Meaning in the Seventeenth Century Print Culture // The Journal of British Studies. 2009. № 4. P. 890-902.

15. Johnson Ch. A General History of the Pyrates / ed. by Manuel Schonhorn. Columbia, SC: the University of South Carolina Press, 1972. 800 p.

16. Копелев Д.Н. «Весёлый Роджер»: мифология и символика пиратского террора // Вопросы истории, 2008. № 12. С. 141-148.

17. Вязовцева Н.О. Золотой век пиратства - Эдвард Тич // Наука: прошлое, настоящее, будущее: сб. ст. междунар. науч.-практ. конф. Уфа: Аэтерна, 2016. C. $99-100$.

18. Rediker M. Villains of All Nations: Atlantic Pirates in the Golden Age. Boston: Beacon Press, 2004. 248 p.
19. Konstam A. Scourge of the Seas: Buccaneers, Pirates and Privateers. Oxford: Osprey Publishing, 2007. 240 p.

20. Маховский Я. История морского пиратства. М.: Наука, 1972. 288 с.

21. Calendar of State Papers, Colonial series: America and West Indies, Vol. 15: 1696-1697 / Ed. by J.W. Fortescue. L.: 1904. June 15, 1696. № 40.

22. Privateering and Piracy in the Colonial Period: Illustrative Documents / Ed. by J.F. Jameson. N.Y.: The Macmillan Company, 1923. P. 170-172.

23. Calendar of State Papers, Colonial series: America and West Indies, Vol. 11: 1681-1685 / Ed. by J.W. Fortescue. L.: 1898. Aug. 29, 1682. № 668.

24. Копелев Д.Н. Раздел Океана в XVI-XVIII веках: Истоки и эволюция пиратства. СПб.: Крига, 2013. 736 с.

25. Calendar of State Papers, Colonial series: America and West Indies, Vol. 27: 1712-1714 / Ed. by C. Headlam. L.: 1926. April 22, 1714. № 651.

26. Calendar of State Papers, Colonial series: America and West Indies, Vol. 27: 1712-1714 / Ed. by C. Headlam. L.: 1926. July 5, 1717. № 635.

\title{
PIRATE REPUBLIC IN THE BAHAMAS: THE CAUSES AND THE IMPACT ON THE SYSTEM OF GOVERNMENT
}

(C) 2020

Pautov Dmitry Alekseevich, postgraduate student of New, Recent History and Methodology Department Moscow Region State University (Moscow, Russian Federation)

Abstract. The subject of the research is the military-political, economic, ideological and natural-geographical reasons for the emergence and characteristics of the organization of the Pirate Republic in the Bahamas. The object of the study is the social relations that developed in the process of development of the pirate community as a special social group, its expansion into the Bahamas of the Caribbean in the 17-18 centuries. Particular attention is paid to the relationship of the British Crown with the pirates and the factors that influenced the transformation of this policy. The author examined in detail the political and legal features of the organization and functioning of the public authority system in the Bahamas during the period of pirate domination. The research methodology was composed of historical, structural, systemic and comparative methods, which made it possible to formulate theoretical conclusions relevant to the processes taking place in the world today and ongoing scientific discussions about the fate of Western civilization, the possibility of building multicultural societies, and the adaptation of political and legal institutions to these processes. The scientific novelty of the study lies in the fact that it is the first experience in the study of the causes and essence of the Pirate Republic in the British colonial system in Russian historiography. It is concluded that, not being a state in the strict sense of the word, the Pirate Republic was a unique experience of social and territorial self-organization. The experience of its emergence and existence left a bright mark in the development of not only the colonial system, but also in world history, as a whole, becoming yet another evidence of the viability of one or another local alternative political model, without a support of influential geopolitical forces and factors.

Keywords: history; piracy; Bahamas; pirate republic; public relations; British colonial system; pirate community; socio-territorial self-organization; free society; western civilization.

\section{ДВОРЯНСТВО СИМБИРСКОЙ ГУБЕРНИИ В КОНЦЕ ХVIII - ПЕРВОЙ ПОЛОВИНЕ ХІХ ВЕКА}

Айзатуллова Алсу Шамилевна, кандидат исторических наук, заведующий кафедрой гуманитарных и социально-экономических дисциплин Ульяновский институт гражданской авиации имени Главного маршала авиации Б.П. Бугаева (2. Ульяновск, Российская Федерация)

Судаков Михаил Александрович, кандидат исторических наук, доцент кафедры гуманитарных и социально-экономических дисциплин; специалист центра развития истории и культуры региона Ульяновский институт гражданской авиации имени Главного мариала авиации Б.П. Бугаева (2. Ульяновск, Российская Федерация);

Центр стратегических исследований Ульяновской области (г. Ульяновск, Российская Федеращия)

Аннотация. Целью статьи является анализ социально-экономического положения дворянства Симбирской губернии в конце XVIII - первой половине XIX века. Характеризуется динамика численности дворян в 
Айзатуллова А.Ш., Судаков М.А

Симбирской губернии (в сравнении с показателями, характерными для Казанской и Пензенской губерний). Проводятся различия между двумя группами дворянства - потомственным и личным. Выявляется удельный вес обеих групп в структуре сословия в Симбирской и других средневолжских губерниях; прослеживается динамика этого показателя. Отмечается, что в Симбирской губернии на протяжении исследуемого периода преобладало потомственное дворянство, хотя удельный вес его сократился. Ещё одной тенденцией стало «одворянивание бюрократии». Авторы показали неоднородность дворянского сословия в регионе по размерам душевладения (стратификация именно по этому критерию является наиболее обоснованной). В рамках изучаемого сословия выделяются высшая, средняя и низшая страты. Анализ состава высшей страты дал возможность авторам выявить дворян, отличавшихся наиболее высоким уровнем благосостояния (П.И. Мятлева, В.П. Орлов-Давыдов, А.М. Потёмкин, А.С. Урусова, Родионовы). Сделан вывод о распространении в первой половине XIX в. залога помещичьих имений и их продажи с аукциона. Это следует считать доказательством оскудения дворянства накануне отмены крепостного права.

Ключевые слова: дворянство; социально-экономическое положение; Симбирская губерния; Среднее Поволжье; численность; корпоративные права; потомственное дворянство; личное дворянство; душевладение; стратификация; высшая страта; средняя страта; низшая страта; имения; крепостные крестьяне; залог.

Сословность общества в дореволюционной России наложила огромный отпечаток на развитие политических и социальных институтов, хозяйства, культуры. В дореформенный период особую роль играло дворянство, являвшееся привилегированным сословием. Представители именно этой социальной группы принимали важнейшие управленческие решения, обладали наиболее значительными возможностями в области экономики, имели решающее значение в формировании элитарной культуры. В связи с этим изучение дворянства представляется вполне актуальным. В нашей статье мы обращаемся к исследованию численности, состава, размеров душевладения дворян конца XVIII - первой половины XIX века, а также анализируем такое явление, как залог помещичьих имений. Выбор хронологических рамок определяется созданием в 1796 г. Симбирской губернии (которая и оказывается в фокусе нашего внимания), а также отменой крепостного права в 1861 г. Мы используем также отчасти сведения по двум другим губерниям Среднего Поволжья - Пензенской и Казанской, сопоставляя их с данными по уже упомянутой Симбирской губернии.

Отечественные исследователи давно изучают историю дворянского сословия. Следует выделить три периода, в рамках которых проводились эти исследования: дореволюционный, советский и постсоветский. В дореволюционный период появились работы, в которых роль «благородного» сословия изображалась некритично, а порой апологетически. Значительное место в исследованиях занимал анализ становления и развития сословных учреждений. При этом в поле зрения авторов были, прежде всего, общероссийские тенденции развития дворянства [1-3].
В работах, опубликованных в советский период, были затронуты различные проблемы истории дворянства. Исследователи анализировали численность и состав упомянутого сословия [4; 5], землевладение [6], политический статус дворян [7; 8]. Отдельные аспекты истории «благородного» сословия рассматривались в обобщающих работах, посвящённых Симбирскому краю $[9 ; 10]$.

Расширение спектра проблем истории дворянства произошло в постсоветский период. В частности, в это время появились работы, в которых анализировался менталитет дворян [11; 12], помещичий патернализм [13], история дворянских родов [14; 15], в историко-культурном контексте рассматривалась роль дворянских усадеб [16; 17]. Плодотворными оказались и региональные исследования, выполненные на материалах Среднего Поволжья [18-23]. В этих работах был проведён анализ различных аспектов деятельности дворян (политических, экономических, социокультурных). В исследованиях постсоветского периода произошёл отход от постулатов марксистско-ленинской идеологии. При этом ощущается дефицит специальных исследований, в которых основным объектом изучения было бы социально-экономическое положение дворянства Симбирской губернии на дореформенном этапе своего развития, таких работ в этот период не появилось. В связи с этим мы полагаем необходимым восполнить этот пробел.

В табл. 1 приведены данные, на основе которых можно судить о динамике численности дворянства в губерниях Среднего Поволжья в конце XVIII - первой половине ХІХ вв.

таблица 1 - Изменения в численности дворян мужского пола губерний Среднего Поволжья в 17951858 гг. (губернии в границах начала XIX в.) [4, с. 162]

\begin{tabular}{|c|c|c|c|c|c|c|c|}
\hline \multirow[b]{2}{*}{ Губернии } & \multicolumn{5}{|c|}{ Ревизии и исчисления } & \multicolumn{2}{|c|}{$\begin{array}{l}\text { Прирост в } 1858 \text { г. по } \\
\text { сравнению с } 1795 \text { г. }\end{array}$} \\
\hline & $\begin{array}{c}\text { по V } \\
\text { ревизии } \\
(1795 \text { г.) }\end{array}$ & $\begin{array}{c}\text { по VII } \\
\text { ревизии } \\
(1816 \text { г.) }\end{array}$ & $\begin{array}{c}\text { по VIII } \\
\text { ревизии } \\
(1834 \text { г.) }\end{array}$ & $\begin{array}{c}\text { по IX } \\
\text { ревизии } \\
(1850 \text { г.) }\end{array}$ & $\begin{array}{c}\text { по } \\
\text { исчислению } \\
(1858 \text { г.) }\end{array}$ & в душах & в $\%$ \\
\hline Казанская & 995 & 747 & 2460 & 1077 & 2932 & 1057 & 133,20 \\
\hline Пензенская & 1462 & 1663 & 2112 & 2446 & 2698 & 1236 & 84,54 \\
\hline Симбирская & 1740 & 2441 & 3007 & 1190 & 2474 & 734 & 42,18 \\
\hline Итого: & 4197 & 4851 & 7579 & 4713 & 8104 & 3907 & 93,09 \\
\hline $\begin{array}{l}\text { Доля дворян } \\
\text { ко всему населению, \% }\end{array}$ & 0,35 & 0,35 & 0,46 & 0,26 & 0,42 & - & - \\
\hline
\end{tabular}


Итак, с 1795 до 1858 гг. численность дворян (муж. пола) Симбирской губернии увеличилась на $42,18 \%$. Среди трёх указанных средневолжских губерний здесь был наиболее низкий темп прироста. Отчасти это объясняется тем, что в 1795 г. именно в этом регионе была самая высокая (в абсолютном выражении) численность представителей этого сословия. К середине XIX в. по этому показателю дворянство Симбирской губернии уступало как казанскому, так и пензенскому дворянству.

Дворяне были наделены рядом «личных прав и преимуществ». Среди них следует выделить основные:

- свобода от службы и, как следствие, особые привилегии при поступлении на службу и при чинопроизводстве;

- свобода от личных податей;

- свобода от телесных наказаний;

- неприкосновенность дворянского достоинства;

- право владеть вотчинами и крепостными.

Кроме того, у дворян были корпоративные права, дарованные им Екатериной II. Согласно учреждению о губерниях 1775 г. и жалованной грамоте 1785 г., дворянство каждой губернии составляло общество, наделённое правами юридического лица. Органами названных обществ являлись собрания, губернский и уездные предводители, депутатское собрание и опека. Действие жалованной грамоты было приостановлено при Павле I, но в годы правления Александра І вновь восстановлено [24; 25, с. 36].

В соответствии с IX томом Свода законов Российской империи, дворянство подразделялось на потомственное и личное. Первая группа имела право владеть недвижимой собственностью и фиксировалась в родословной книге, которую вело дворянское депутатское собрание. В первую часть родословной книги вносилось «дворянство жалованное или действительное», во вторую - «дворянство военное», в третью - «дворянство по чинам и орденам», в четвёртую - «иностранные роды», в пятую - «титулами отмеченные роды», в заключительную шестую «древние благородные дворянские роды». На основании исследования В.Н. Поливанова [26, с. 9-48] можно получить приблизительное представление о состоянии «дворянского корпуса» региона до отмены крепостного права. По состоянию на 1860 г. в Симбирской губернии было 579 родов из числа упомянутых в документе (время записи в родословную книгу ещеё нескольких семей не указано: в первую часть внесено пять таких семей, в третью - одна, в шестую - три. - A.A., М.C.). К первой части родословной книги относилось 209 из них (36,1\% от общего числа), ко второй $-87(15,0 \%)$, к третьей -80 $(13,8 \%)$, к четвёртой - ни одного, к пятой -11 $(1,9 \%)$, к шестой - 192 (33,2\%). Таким образом, статистическая обработка данного источника показывает существенное преобладание дворянских семей двух категорий - первой (жалованное дворянство) и шестой (древние дворянские роды). Тем не менее стоит сделать важную оговорку. Отчёт симбирского губернского предводителя за 1862 г. содержит сведения о 1350 дворянских родах. В.Н. Поливанов объяснил значительное уменьшение числа дворянских семей к 1900 г. (их на тот момент было зафиксирова- но 826) истреблением в симбирском пожаре 1864 г. четырёх частей (2-й, 3-й, 4-й, 5-й) родословной книги, после которого многие прежние роды «более не возобновлялись» [26, с. 4-5]. В результате - на основании работы В.Н. Поливанова - мы располагаем подробными сведениями только о части (42,9\%) учтённых до пожара 1350 дворянских семей. Потому приведённые выше результаты подсчётов следует использовать с известной долей осторожности.

Выделим несколько способов получения потомственного дворянства (отчасти этот фактор и определял структуру родословной книги губернии):

- Высочайшее пожалование;

- производство в чин (с момента издания петровской «Табели о рангах» происходило постепенное повышение чина, дающего дворянский статус. С 1856 г. права потомственного дворянина приобретались в результате достижения на гражданской службе чина действительного статского советника, на военной службе - чина полковника, а во флоте - чина капитана 1-го ранга);

- приобретение дворянства вследствие получения первых степеней всех орденов, а также всех степеней ордена Св. Владимира и Св. Георгия (но это не касалось купцов, которые в случае получения орденов приобретали статус почётных граждан);

- многолетняя служба деда и отца (не менее 20 лет для каждого) в чинах, достаточных для статуса личного дворянина. Их потомок мог по достижении 17 лет и по вступлении в службу просить о включении его в число потомственных дворян [24; 25, с. 36$]$.

Личное дворянство приобреталось следующими способами:

- монаршим пожалованием;

- получением на военной службе чина оберофицера, а на гражданской - чина 9-го класса или (в случае отставки) чина полковника, капитана 1-го ранга или действительного статского советника;

- получением орденов (за исключением тех, которые давали право на приобретение статуса потомственного дворянина) [24].

Данные, которые содержатся в табл. 2, показывают изменение состава указанного сословия в губерниях Среднего Поволжья на протяжении первой половины XIX в.

Из таблицы видно, что в Симбирской губернии сохранялось преобладание потомственного дворянства. При этом состав губернского дворянства существенно изменился: если в 1816 г. потомственные дворяне составляли $72,10 \%$ от общей численности сословия, то в 1858 г. их было зафиксировано всего $53,68 \%$. В Казанской губернии тенденция к снижению удельного веса потомственных дворян проявилась более отчётливо: этот показатель сократился с $69,88 \%$ до $39,90 \%$, и данная группа дворян, таким образом, утратила преобладание. И лишь в Пензенской губернии произошло заметное увеличение удельного веса этой группы дворянства - с 29,89\% до $64,75 \%$. Личные же дворяне, преобладавшие в 1816 г. в Пензенской губернии, в 1858 г. доминировали лишь в Казанской губернии. Следовательно, в Симбирской и Казанской губерниях шёл активный процесс «одворянивания бюрократии». 
Айзатуллова А.Ш., Судаков М.А.

Таблица 2 - Состав дворянства (мужского пола) в губерниях Среднего Поволжья в 1-й половине XIX в. [4, с. 166]

\begin{tabular}{|c|c|c|c|c|c|c|}
\hline \multirow[b]{2}{*}{ Губернии } & \multicolumn{3}{|c|}{1816 г. } & \multicolumn{3}{|c|}{1858 г. } \\
\hline & $\begin{array}{c}\text { Потомственных } \\
\text { дворян }\end{array}$ & $\begin{array}{l}\text { Личных } \\
\text { дворян }\end{array}$ & Всего & $\begin{array}{c}\text { Потомственных } \\
\text { дворян }\end{array}$ & $\begin{array}{l}\text { Личных } \\
\text { дворян }\end{array}$ & Всего \\
\hline Казанская & 522 & 225 & 747 & 1170 & 1762 & 2932 \\
\hline Пензенская & 497 & 1166 & 1663 & 1747 & 951 & 2698 \\
\hline Симбирская & 1760 & 681 & 2441 & 1328 & 1146 & 2474 \\
\hline Итого: & 2779 & 2072 & 4851 & 4245 & 3859 & 8104 \\
\hline Доля по губерниям, \% & 57,28 & 42,72 & 100 & 52,39 & 47,61 & 100 \\
\hline
\end{tabular}

Неоднородность дворянства отчётливо проявлялась также с точки зрения доходов, образования и престижа. Главным критерием материального благосостояния дворян в изучаемый период было число крепостных крестьян. Как показывает Б.Н. Миронов, образование, престиж и влияние дворянина находились в зависимости от дохода, который давали крепостные. Принято выделять три страты: низшую, среднюю и высшую. Низшая страта, как правило, состояла из беспоместных и мелкопоместных (с числом крепостных мужского пола менее 21) дворян, средняя - из среднепоместных (с числом крепостных от 21 до 100), высшая - из крупнопоместных (с числом крепостных более 100) дворян. Возможность вести «дворянский» образ жизни была лишь у представителей средней и высшей страты. Личные же дворяне не имели права владеть крепостными людьми, и основными статьями их дохода являлись жалованье или пенсия за службу [27, с. 86$]$.

Накануне проведения крестьянской реформы в Симбирской губернии, по данным казённой палаты, помещиков, владевших менее 21 души муж. пола, было 472; от 21 до 100 - 587; от 100 до $500-481$; от 500 до 1000 - 78; владевших 1000 и большим числом душ муж. пола - 30 [28, с. 257] (приводятся сведения не о количестве дворян-душевладельиев, а о количестве «владельческих семейств». - А.А., М.С.). Иными словами, к низшей страте («бедные», по словам А.И. Липинского) относилось 28,64\% дворян, к средней («достаточные») - 35,61\%, а к высшей страте дворянства («весьма достаточные») - 35,74\% от общей численности представителей этого сословия. При подсчёте дворян, входивших в высшую страту, мы суммировали численность дворян, владевших не менее чем 100 душами мужского пола.

Сведения об имениях, населённых большим количеством крепостных и дворовых людей, были собраны в Российской империи по губерниям также накануне отмены крепостного права (при этом имеется некоторое расхождение с приведённой выше информацией о крупнопоместных имениях; возможно, это объясняется различными методиками подсчёта). Данные по Симбирской губернии, представляющие для нас интерес, представлены в табл. 3.

Приведенные в таблице сведения позволяют установить, что наибольшее количество имений было характерно для Карсунского, Симбирского и Сызранского уездов $(85,81$ и 78 имений соответственно), а наименьшее - для Алатырского и Буинского уездов (22 и 24 имения соответственно). Наибольшее количество крепостных и дворовых людей в имениях было зафиксировано в Карсунском и Сызранском уездах (36195 и 34159 чел. соответственно), а наименьшее - в Буинском уезде (5429 чел.). Таким образом, представителям высшей страты дворян губернии принадлежало 78,67\% всех крепостных крестьян и $66,03 \%$ всех дворовых людей губернии (Подсчёты мы произвели, опираясь на данные о количестве «временнообязанных крестьян» и дворовых людей мужского пола по состоянию на 1858 г. - A.A., M.C.). Показатель, характерный для симбирского поместного дворянства, был несколько ниже общероссийского (высшей страте принадлежал $81 \%$ всех крепостных крестьян) [27, с. 88]. Следовательно, подавляющее большинство крепостных края, равно как и империи в целом, находилось во владении представителей дворянской элиты.

Среди крупных помещиков выделялись П.И. Мятлева (в Алатырском уезде - 6176 крепостных муж. пола; 364 дворовых людей муж. пола; в Курмышском уезде - 1418; 85 соответственно); граф В.П. Орлов-Давыдов (в Сызранском уезде - 6157; 49; в Сенгилеевском уезде - 717 крепостных муж. пола); А.М. Потёмкин (в Алатырском уезде - 6519; 9); княгиня А.С. Урусова (в Алатырском уезде - 2179; 57); Н.П., Д.П., М.П., В.П. и А.П. Родионовы (в Карсунском уезде - 2129 крепостных муж. пола и 186 дворовых людей муж. пола) [29, с. $10,28,34,36,18]$.

Правительство пыталось оказывать покровительство малоимущим представителям дворянства. Например, дворяне имели возможность брать в оброк земли из казённого фонда. Так, в Самарском уезде в 1849 г. три участка использовались для выпаса скота небогатыми дворянами Б. Селивановым, К. и И. Межениновыми, И. Болотовым и Ф. Шебановым «с прочими их товарищами» [30, л. 3,3 об.].

Несмотря на поддержку дворянства со стороны правительства, в рассматриваемый период начинает просматриваться тенденция разорения дворянства, утрата помещиками земельных владений и рабочих рук. Так, в 1797 г. помещица П.Н. Гурьева заявляла о «надобности» занять из государственного заёмного банка деньги под заклад своего недвижимого имения (сёла Никитино, Малая Кандарать и Белый ключ, деревни Степановка и Висловка Котяковской округи) [31, л. 15,15 об.]. П.Н. Ивашев в 1802 и 1810-1811 гг. брал займы в Петербургском и Московском опекунском советах (в первом случае - 19900 руб. под залог 398 ревизских душ и земли д. Ивашевки, а во втором случае - под залог своих имений в Симбирской, Владимирской, Костромской и Пензенской губерниях). Родовое имение помещиков Тургеневых в 1829 г. было заложено в опекунском совете за 142 тыс. руб., а позднее продано [10, с. 78]. Порой к залогу своих крестьян пытались прибегнуть и наиболее крупные крепостники. Так, в 1824 г. в Симбирской палате гражданского суда рассматривалось прошение тайной советницы П.И. Мятлевой (урождённой графини Салтыковой), стремившейся заложить в Санкт-Петербургском или Московском опекунском совете 1243 души (речь шла о лицах, проживавших в её имении в Алатырском уезде) [32, л. 1]. Прибегали помещики и к перезалогу своих владений. В 1835 г. Палата гражданского суда Симбирской губернии выдала свидетельство, разрешающее перезалог имения Ф.В. Самарина в Сызранском уезде [33, л. 1,1 об.]. 
Таблица 3 - Имения Симбирской губернии, населённые 100 или более крепостными и дворовыми людьми (мужской пол, сведения за 1860 г.) [29]

\begin{tabular}{|l|c|c|c|c|}
\hline \multicolumn{1}{|c|}{ Уезды } & $\begin{array}{c}\text { Количество } \\
\text { имений }\end{array}$ & $\begin{array}{c}\text { Численность } \\
\text { крепостных людей }\end{array}$ & $\begin{array}{c}\text { Численность } \\
\text { дворовых людей }\end{array}$ & $\begin{array}{c}\text { Всего крепостных } \\
\text { иворовых людей }\end{array}$ \\
\hline Симбирский & 81 & 19859 & 1496 & 21355 \\
\hline Алатырский & 22 & 17462 & 516 & 17978 \\
\hline Ардатовский & 58 & 16363 & 695 & 5429 \\
\hline Буинский & 24 & 5029 & 400 & 36195 \\
\hline Карсунский & 85 & 34583 & 1612 & 15740 \\
\hline Курмышский & 48 & 14679 & 861 & 18993 \\
\hline Сенгилеевский & 60 & 18132 & 1831 & 34159 \\
\hline Сызранский & 78 & 32328 & 8472 & 166907 \\
\hline \multicolumn{1}{|c|}{ Итого по всем уездам: } & 456 & 158435 & & \\
\hline
\end{tabular}

Примечание. Среди крепостных людей особо выделялись лица на дворовом положении и фабричные.

Как следует из губернаторского отчёта за 1860 г., из 1607 помещичьих имений губернии 897 (или $55,8 \%)$ значились «заложенными и перезаложенными» в банках и ссудно-сохранных кассах, а 230 из числа последних были в результате неуплаты взносов описаны и проданы с аукциона. В 1861 г. количество заложенных и перезаложенных имений увеличилось до $60 \%$ [34, с. 23]. (И.А. Стеценко приводил несколько иной показатель за 1860 г.: по его данным, в губернии было заложено и перезаложено 897 имений, или $65,8 \%$ от общего количества помещичьих имений [10, с. 77]. Но эти данные вызывают меньше доверия, так как не указан источник, из которого исследователь черпал информацию).

Дворяне середины XIX века оказались в непростом материальном положении во многом из-за особенностей стиля жизни своих предков, имевших склонность к роскоши и оставивших после себя значительные долги. Оскудение помещиков и необходимость закладывать имения было общероссийским явлением, ставшим, по мнению В.И. Буганова, одной из причин отмены крепостного права [25, с. 37].

Итак, можно сделать ряд выводов. На протяжении изучаемого периода численность дворян (муж. пола) Симбирской губернии увеличилась на 42,18\%. Такой темп прироста был наиболее низким среди трёх средневолжских губерний, данные по которым мы использовали. Анализ состава сословия на территории исследуемого региона показал, что состав губернского дворянства существенно изменился: если в 1816 г. потомственные дворяне составляли $72,10 \%$ от общей численности сословия, то в 1858 г. их было зафиксировано всего 53,68\%. В регионе наблюдался процесс «одворянивания бюрократии», проявлением которого стал рост удельного веса личных дворян.

К высшей страте относилось 35,74\% потомственных дворян Симбирской губернии. При этом в их руках находились 78,67\% всех крепостных крестьян и $66,03 \%$ всех дворовых людей этого региона. Это свидетельствует о больших возможностях крупнопоместного дворянства в аграрном секторе края.

Но, несмотря на потенциал дворянской элиты, к концу дореформенной эпохи прослеживается тенденция к экономическому ослаблению «благородного» сословия в целом. Доказательством этого служит распространение в губернии такого явления, как залог помещичьих имений.

\section{Список литературы:}

1. Романович-Славатинский А.В. Дворянство в России от начала XVIII века до отмены крепостного права. СПб.: Тип. Министерства внутренних дел, 1870. $594 \mathrm{c}$.

2. Яблочков М.Т. История дворянского сословия в России. СПб.: Тип. А.М. Котомина, 1876. 680 с.

3. Корф С.А. Дворянство и его сословное управление за столетие 1762-1855 гг. СПб.: Тип. Тренке и Фюсно, 1906. 720 с.

4. Кабузан В.М., Троицкий С.М. Изменения в численности, удельном весе и размещении дворянства в России в 1782-1858 гг. // История СССР. 1971. № 4. С. $153-168$.

5. Шепукова Н.М. Об изменении размеров душевладения помещиков Европейской России в первой четверти XVIII - первой половине XIX в. // Ежегодник по аграрной истории восточной Европы. 1963 г. Вильнюс: Минтис, 1964. С. 388-419.

6. Водарский Я.Е. Дворянское землевладение в России в XVII - первой половине XIX в. М.: Наука, $1988.303 \mathrm{c}$.

7. Ерошкин Н.П. История государственных учреждений дореволюционной России. 3-е изд., перераб. и доп. М.: Высшая школа, 1983. 352 с.

8. Сафонов М.М. Проблема реформ в правительственной политике России на рубеже XVIII и XIX вв. Л.: Наука, Ленингр. отд-ние. 1988. 248 с.

9. Гриценко Н.П. Очерки по истории города Симбирска-Ульяновска и Ульяновской области. Т. 1. Ульяновск: Ульяновская правда, 1948. 240 с.

10. Край симбирский: Краткий историч. очерк. Саратов: Приволж. кн. изд-во (Ульян. отд-ние), 1989. $256 \mathrm{c}$.

11. Марасинова Е.Н. Психология элиты российского дворянства последней трети XVIII в. (по материалам переписки). М.: РОССПЭН, 1999. 302 с.

12. Смахтина М.В. Русское поместное дворянство в XIX в.: эволюция этических норм, представлений и практики в социальной и экономической сферах: автореф. дис. ... канд. ист. наук. М., 2008. 24 с.

13. Рянский Р.Л. Развитие помещичьего хозяйства Черноземного центра в первой половине XIX века: автореф. дис. ... д-ра ист. наук. Курск, 2015. 49 с. 
14. Фролова С.А. Казанская ветвь дворянского рода Молоствовых (вторая половина XVIII - 1861 г.): автореф. дис. ... канд. ист. наук. Казань, 1998. 23 с.

15. Виккел О.Л. Семья Ивашевых в контексте русской дворянской культуры конца XVIII-XIX веков: автореф. дис. ... канд. ист. наук. М., 2000. 34 с.

16. Пономарёва М.В. Дворянская усадьба в культурно-художественной жизни России: XVIII-XIX вв.: автореф. дис. ... канд. ист. наук. М., 2005. 23 с.

17. Ларионова М.Б. Дворянская усадьба на Среднем Урале: вторая половина XVIII - начало XX в.: автореф. дис. ... канд. ист. наук. Екатеринбург, 2006. 19 с.

18. Дементьева Е.Ю. Провинциальное дворянство Среднего Поволжья первой половины XIX века: автореф. дис. ... канд. ист. наук. Самара, 1999. 17 с.

19. Селиверстова Н.М. Дворянство Среднего Поволжья накануне проведения Великих реформ: автореф. дис. ... канд. ист. наук. Самара, 1994. 20 с.

20. Шевнина О.Е. Облик провинциального дворянства в конце 1850-х - 1870-е гг.: на материалах губерний Среднего Поволжья: автореф. дис. ... канд. ист. наук. Пенза, 2003. 24 с.

21. Смирнов Ю.Н. Крупная крепостная вотчина и освоение земель Среднего Поволжья в последней трети XVIII - первой половине XIX века (по материалам владений Орловых и Орловых-Давыдовых в районе Самарской Луки // Вестник Самарского университета. История, педагогика, филология. 2012. № 8/2. С. 101-109.

22. Мурашов Д.Ю. Провинциальное дворянство в конце 50-х - 70-х гг. ХIX в.: на материалах Пензенской губернии: автореф. дис. ... канд. ист. наук. Саратов, 2004. 25 с.

23. Першин С.В. Сословные учреждения в России в первой половине XIX века: по материалам дворян- ских и городских обществ средневолжских губерний: автореф. дис. ... д-ра ист. наук. Саранск, 2010. 50 с.

24. Дворянство [Электронный ресурс] // Энциклопедия Брокгауза и Ефрона. - http://brocgaus.ru/text/ 033/893.htm.

25. Буганов В.И. Российское дворянство // Вопросы истории. 1994. № 1. С. 29-41.

26. Материалы к истории Симбирского дворянства. 1781-1900 / собр. и изд. губ. предводителем дворянства В.Н. Поливановым. Симбирск: Типолитогр. А.Т. Токарева, 1900. 181 с.

27. Миронов Б.Н. Социальная история России периода империи (XVIII - начало XX в.): В 2-х т. 3-е изд., испр., доп. Т. 1. Генезис личности, демократической семьи, гражданского общества и правового государства. СПб.: Дмитрий Буланин, 2003. 547 с.

28. Материалы для географии и статистики России, собр. офицерами Генерального штаба. Симбирская губерния. Ч. 1. СПб.: Военная Типография, 1868. $566 \mathrm{c}$.

29. Приложения к Трудам Редакционных комиссий, для составления Положений о крестьянах, выходящих из крепостной зависимости. Сведения о помещичьих имениях. Т. III. Извлечения из описаний имений, по Великороссийским губерниям. СПб.: Тип. В. Безобразова и комп., 1860. 341 с.

30. ГАУО (Государственный архив Ульяновской области). Ф. 76. Оп. 8. Д. 144.

31. ГАУО. Ф. 995. ОП. 1. Д. 4.

32. ГАУО. Ф. 752. ОП. 4. Д. 21.

33. ГАУО. Ф. 866. ОП. 1. Д. 3.

34. Клеянкин А.В. Крестьяне и крестьянское хозяйство Симбирской губернии в конце XVIII - первой половине XIX века: автореф. дис. ... д-ра ист. наук. Тарту, 1974. 46 с.

\title{
THE NOBILITY OF SIMBIRSK GOVERNORATE AT THE END OF THE 18 ${ }^{\text {TH }}$ - THE FIRST HALF OF THE 19 ${ }^{\text {TH }}$ CENTURY
}

(C) 2020

\author{
Aizatullova Alsu Shamilievna, candidate of historical sciences, \\ head of Humanities and Social-Economic Disciplines Department \\ Ulyanovsk Institute of Civil Aviation named after chief Marshal of aviation B.P. Bugaev \\ (Ulyanovsk, Russian Federation)
}

Sudakov Mikhail Aleksandrovich, candidate of historical sciences, associate professor of Humanities and Social-Economic Disciplines Department; specialist of Center for Development of History and Culture of Region Ulyanovsk Institute of Civil Aviation named after chief Marshal of aviation B.P. Bugaev (Ulyanovsk, Russian Federation); Center for Strategic Studies of Ulyanovsk Region (Ulyanovsk, Russian Federation)

Abstract. The goal of the paper is to analyze the socio-economic situation of the Simbirsk Governorate nobility in the late $18^{\text {th }}$ - first half of the $19^{\text {th }}$ century. The authors have characterized the dynamics of the number of nobles in Simbirsk Governorate (in comparison with indicators of Kazan Governorate and the Penza Governorate). The nobility is divided into two groups - hereditary and personal. The authors reveal the position of both groups in the structure of the estate in Simbirsk Governorate and other Middle Volga governorates and trace the dynamics of this indicator. It is noted that hereditary nobility prevailed in Simbirsk Governorate during the study period, although its specific gravity decreased. Another trend was the «bureaucracy». The authors have shown the heterogeneity of the nobility in the region in terms of soul ownership (stratification by this criterion is the most justified). Within the studied class, the highest, middle and lower strata are distinguished. The analysis of the highest stratum composition made it possible for the authors to identify the nobles who were distinguished by the highest level of well-being (P.I. Myatleva, V.P. Orlov-Davydov, A.M. Potemkin, A.S. Urusova, the Rodionovs). The authors come to the conclusion that there was a distribution of landlord estates pledge and their auctioning in the first half of the $19^{\text {th }}$ century. This should be considered evidence of the impoverishment of the nobility on the eve of the Emancipation Reform.

Keywords: nobility; socio-economic situation; Simbirsk Governorate; Middle Volga; strength corporate rights; hereditary nobility; personal nobility; stratification; highest stratum; middle stratum; lower stratum; estates; serfs; pledge. 